Marquette University

e-Publications@Marquette

School of Dentistry Faculty Research and

Publications

Dentistry, School of

$1-1-2010$

\title{
Treatment of Gingival Recession
}

Moawia M. Kassab

Marquette University, moawia.kassab@marquette.edu

Hala Badawi

Marquette University

Andrew R. Dentino

Marquette University, andrew.dentino@marquette.edu

Accepted version. Dental Clinics of North America, Vol. 54, No. 1 (January 2010): 129-140. DOI. (C) 2010 Elsevier B.V. Used with permission. 
Marquette University

e-Publications@Marquette

\section{Dentistry Faculty Research and Publications/School of Dentistry}

This paper is NOT THE PUBLISHED VERSION; but the author's final, peer-reviewed manuscript. The published version may be accessed by following the link in the citation below.

Dental Clinics of North America, Vol. 54, No. 1 (2010): 129-140. DOI. This article is C Elsevier (WB Saunders) and permission has been granted for this version to appear in e-Publications@Marquette. Elsevier (WB Saunders) does not grant permission for this article to be further copied/distributed or hosted elsewhere without the express permission from Elsevier (WB Saunders).

\section{Treatment of Gingival Recession}

Keywords

Gingival recession, Gingival grafting, Connective tissue grafting, Guided tissue regeneration, Coronally positioned flap

Gingival recession is an intriguing and complex phenomenon. Recession frequently disturbs patients because of sensitivity and esthetics. Many surgical techniques have been introduced to treat gingival recession, including those involving autogenous tissue grafting, various flap designs, orthodontics, and guided tissue regeneration (GTR). This article describes different clinical approaches to treat gingival recession with emphasis on techniques that show promising results and root coverage.

\section{Etiology and prevalence}

Recession can be defined as the displacement of the gingival margin apically from the cementoenamel junction (CEJ), or from the former location of the CEJ where restorations have distorted the location or appearance of the CEJ. Gingival recession can be localized or generalized, and be associated with one or more surfaces. $\underline{1}$ 
Many people exhibit generalized gingival recession without any awareness of the condition and without symptoms. However, patients are often anxious about gingival recession for one or several reasons, including fear of tooth loss, dentinal hypersensitivity, or poor esthetics. Because many possible contributing factors interact to contribute to gingival recession, it is difficult to predict whether further changes in gingival recession may occur at a given site.

Albandar and Kingman ${ }^{2}$ studied the prevalence of gingival recession among subjects 30 to 90 years old. Using a sample of 9689 subjects, they projected that 23.8 million persons in the United States have one or more tooth surfaces with $3 \mathrm{~mm}$ or more gingival recession. Those investigators also found that the prevalence of $1 \mathrm{~mm}$ or more recession in persons 30 years and older was 58\%, and increased with age. Males had significantly more gingival recession than females, and African Americans had significantly more gingival recession than members of other racial/ethnic groups. Recession also was more prevalent

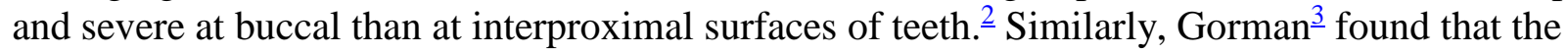
frequency of gingival recession increased with age, and was greater in males than females of the same age. Malpositioned teeth and toothbrush trauma were found to be the most frequent etiologic factors associated with gingival recession. $\cdot$ Recession associated with labially positioned teeth occurred in $40 \%$ of patients 16 to 25 years old, and increased to $80 \%$ of patients in the 36 - to 86 -year-old group. ${ }^{3}$ Those findings were corroborated by Gorman, $\stackrel{4}{-}$ who examined 4000 subjects and found that the incidence of gingival recession increased with age.

The indications for surgical treatment of gingival recession include reducing root sensitivity, minimizing cervical root caries, increasing the zone of attached gingiva, and improving esthetics.

\section{Connective tissue grafting}

One goal of soft tissue grafting is root coverage. To accomplish that goal, many techniques and flap designs have been used, some of which do not require a donor site (pedicle grafts), while others do (free autogenous grafts). The success rates of root coverage procedures vary because coverage depends on several factors, including location and classification of the gingival recession and the technique used. The gingival dimension most commonly assessed is the height (distance between the soft tissue margin and the mucogingival line measured in millimeters). An increase in gingival height independent of the number of millimeters is considered a successful outcome of gingival augmentation procedures. $\underline{5}$

\section{Pedicle grafts}

Pedicle grafts differ from free autogenous soft tissue grafts in that the base of the pedicle flap contains its own blood supply, which nourishes the graft and facilitates the reestablishment of vascular union with the recipient site. Pedicle grafts may be partial or full thickness. ${ }^{\underline{6}} \underline{7}$ In a clinical human study, Wood and colleagues $\underline{\underline{\theta}}$ used reentry procedures to compare crestal radicular bone responses to full- and partialthickness flaps. He concluded that regardless of the flap procedure, loss of crestal bone depended on thickness, with the thinnest radicular bone associated with greater postoperative bone loss. The mean bone loss for full- and partial-thickness flaps was $0.62 \mathrm{~mm}$ and $0.98 \mathrm{~mm}$, respectively.

The term lateral sliding flap was first introduced by Grupe and Warren. ${ }^{9}$ Miller and Allen ${ }^{10}$ have noted that that term now generally refers to the laterally positioned pedicle graft (LPPG). An LPPG cannot be 
performed unless there is significant gingiva lateral to the site of recession. A shallow vestibule also may jeopardize outcomes. Although the use of the LPPG provides an ideal color match, it often is inadequate for the treatment of multiple recessions.

Pedicle grafts using an edentulous area as a donor site also have been proposed to correct gingival recession..$^{11}$ The procedure is particularly useful in cases where the attached gingiva on facial surfaces of two or three consecutive teeth is inadequate. That technique involves the development of partialthickness flaps around the involved teeth, sliding the entire flap the width of half a tooth, and placing the interdental papillary tissues over the buccal surfaces of the affected teeth. ${ }^{12}$

Cohen and Ross $\frac{13}{3}$ proposed a double-papilla repositioned flap to cover defects where an insufficient amount of gingiva was present, or where there was an inadequate amount of gingiva in an adjacent area for a lateral sliding flap. The papillae from each side of the tooth are reflected and rotated over the midfacial aspect of the recipient tooth and sutured. The only advantage of this technique is the dual blood supply and denudation only of interdental bone. The disadvantages may include pulling of the

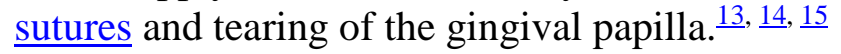

\section{Coronally Positioned Grafts}

Bernimoulin and colleagues $\frac{16}{16}$ first described the coronally positioned graft subsequent to grafting with a free graft (ie, a two-stage procedure).

First, a free autogenous soft tissue graft is placed apical to an area of denuded root. After healing, the flap is coronally repositioned. The requirements for the success of coronally positioned grafts include (1) the presence of shallow crevicular depths on proximal surfaces, (2) approximately normal interproximal bone heights, (3) tissue height within $1 \mathrm{~mm}$ of the CEJ on adjacent teeth, (4) adequate healing of the free graft before coronal positioning, (5) reduction of any root prominence within the plane of the adjacent alveolar bone, and (6) adequate release of the flap to prevent retraction during healing. The second-stage procedure uses a split-thickness dissection with mesial and distal vertical releasing incisions until adequate flap mobility is obtained. The flap is sutured 0.5 to $1 \mathrm{~mm}$ coronal to the CEJ and covered with a periodontal dressing..$^{17}$

Coronally positioned flaps were compared with lateral sliding flaps in the treatment of localized gingival recessions. ${ }^{18,19}$ In a 6-month report, both techniques rendered satisfactory results, and no differences in tissue coverage, sulcus depth, or gain of attached gingiva were reported. An average of $2.7 \mathrm{~mm}$ of soft tissue coverage was obtained, with average recession coverage of $67 \%$. The only difference between the two techniques was an increase in root exposure of approximately $1 \mathrm{~mm}$ at the lateral sliding flap donor site, while no additional recession was observed with the coronally positioned flap. Results were stable for 3 years.

Allen and Miller $\underline{\underline{20}}$ used single-stage coronally positioned flaps in the treatment of shallow marginal recession. The Miller class I defects had a minimum keratinized tissue width of $3 \mathrm{~mm}$, with recession between 2.5 to $4 \mathrm{~mm}$. The technique consisted of citric acid root treatment, a split-thickness flap extending into the vestibule, and surface gingivoplasty of the papillae to produce a bleeding bed. Flaps were sutured into position and dressed. Complete root coverage was attained in $84 \%$ of the sites, with a 
mean root coverage gain of $3.2 \mathrm{~mm}$. Similarly, Harris ${ }^{21}$ reported a $98 \%$ success rate of root coverage in class I defects by using the coronally positioned graft technique.

Tarnow $\underline{\underline{22}}$ described the semilunar coronally positioned flap technique. An incision is made that follows the curvature of the free marginal gingiva and extends into the papillae, staying at least $2 \mathrm{~mm}$ from the papilla tip on either side. The incision is made far enough apically to ensure that the apical portion of the flap rests on bone after repositioning. A split-thickness dissection of the flap is made and the flap is repositioned and held in place with light pressure and a periodontal dressing. The advantages of that technique include no tension on the flap after repositioning, no shortening of the vestibule, no reflection of the papillae (thereby avoiding esthetic compromise), and no suturing.

\section{Free autogenous soft tissue grafts}

Both the epithelialized palatal graft and the subepithelial connective tissue graft offer a more versatile solution for root coverage than does the laterally positioned or coronally positioned pedicle flaps. There is adequate donor tissue, a shallow vestibule does not compromise the procedure, and multiple recessions can be treated. Two kinds of autogenous grafts can be used for root coverage. One consists of an epithelialized layer, while the other does not (or contains a small epithelialized collar).

\section{Free Epithelialized Autogenous Gingival Grafts}

Sullivan and Atkins ${ }^{\underline{23}}$ were the first to explore the feasibility and healing of the free gingival graft. This procedure involves the preparation of a recipient site, which is accomplished by supraperiosteal dissection to remove epithelium and connective tissue to the periosteum.

Some of the common areas for donor material include edentulous ridges, attached gingiva, and palatal gingiva. Because of shrinkage during healing, donor tissue should be approximately 33\% larger than the

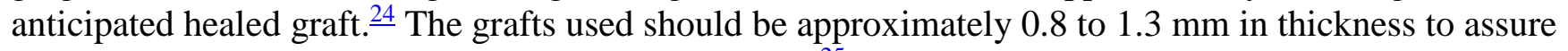
that there is an adequate connective tissue component. $\underline{25}$

In a 2-year study comparing graft versus no graft, plaque control was more important than the width of the attached gingiva in determining eventual breakdown and recession. ${ }^{26}$ Investigators also found that the use of the free gingival graft was a predictable means of increasing the width of the attached gingiva. In a follow-up study 2 years later, the same investigators reported similar results except that $10 \%$ of the nongrafted cases showed additional soft tissue recession compared with grafted sites with equivalent plaque scores. $\underline{27}$

Free gingival grafting has been used as a single procedure to cover denuded root surfaces. $\underline{28}$ The recipient bed is extended one tooth-width lateral to the denuded roots, and $5 \mathrm{~mm}$ apical to the gingival margin of the denuded root. The investigators suggested that donor tissue cover the gingival bed and extend at least $3 \mathrm{~mm}$ apical to the margin of the denuded root, using a graft of approximately $1.5 \mathrm{~mm}$ uniform thickness. In 50 randomly selected cases, recessions less than $3 \mathrm{~mm}$ had $95.5 \%$ root coverage, recessions 3 to $5 \mathrm{~mm}$ had $80.6 \%$ coverage, and recessions more than $5 \mathrm{~mm}$ had $76.6 \%$ coverage. 
Miller $\underline{\underline{29}}$ described a technique for root coverage using a free soft tissue autograft with citric acid treatment. Predictable root coverage depended upon the severity and classification of gingival recession. After root planing, citric acid application was performed, followed by horizontal incisions at the level of the CEJ to preserve the interdental papillae. Vertical incisions at proximal line angles of adjacent teeth facilitate completion of bed preparation. A thick palatal graft with a thin layer of submucosa was placed on a moderately bleeding bed and stabilized with sutures at the papillary and apical ends of the graft extending into periosteum. Results of 100 consecutively placed grafts showed $100 \%$ root coverage in class I defects and $88 \%$ coverage in class II. The average root coverage for all sites was $3.8 \mathrm{~mm}$ with a mean clinical attachment gain of $4.5 \mathrm{~mm}$.

Although Miller reported a combined 90\% success rate in achieving 100\% root coverage, his 100 cases included 94 in the mandible and only 6 in the maxilla.

\section{Connective Tissue Autogenous Grafts}

The use of connective tissue grafts for root coverage was first reported by Langer and Langer. $\underline{30} \mathrm{~A}$ partial-thickness flap with two vertical incisions was elevated on the recipient site, followed by placement of the graft (which is collected from the palate by a double parallel incision technique). The flap is coronally positioned to attempt to cover the graft and benefit from a double blood supply. They reported an increase of 2 to $6 \mathrm{~mm}$ of root coverage in 56 cases over 4 years.

Raetzke $^{31}$ described an envelope technique for obtaining root coverage using connective tissue grafts. In that technique, the collar of marginal tissue around a localized area of recession is excised, the root is debrided and planed, and a split-thickness envelope created around the denuded root surface. The graft was collected from the palate by means of the double parallel incision technique. The connective tissue graft is placed in the previously created envelope covering the exposed root surface. Overall, $80 \%$ of the exposed root surfaces were covered. Similarly, Allen $\underline{32}$ reported an $84 \%$ success rate for root coverage using that same technique.

Jahnke and colleagues ${ }^{33}$ compared the results of free gingival and connective tissue grafts for root coverage in nine patients. Paired defects were selected and assessed preoperatively, as well as 3 and 6 months postoperatively. Root coverage averaged for $43 \%$ for the free gingival graft group, and $80 \%$ for the connective tissue graft group. Borghetti and Louise, $\underline{\underline{34}}$ in their split-mouth controlled clinical study, reported a $70 \%$ success rate of root coverage 1 year postoperatively.

Most of the studies that used the connective tissue grafts for root coverage did not attempt to remove the epithelial collar from the graft, but when Bouchard and colleagues $\frac{35}{2}$ did so, no additional statistically significant benefits were observed (65\% with collar, $70 \%$ without).

When the connective tissue graft was compared with the free gingival graft for root coverage, Paolantonio and colleagues $\frac{36}{6}$ found in a 5-year postoperative study that the connective tissue graft provided a predictable percentage of root coverage (85\%), while the free gingival graft presented only a $53 \%$ success rate. They concluded that connective tissue grafting is a long-term predictable procedure for root coverage. 
A variety of techniques have been used to collect the connective tissue graft, including parallel incisions and free gingival knife methods with no significant difference in the percentage of root coverage. $\frac{37}{}$

\section{Combination of one or more techniques}

To increase the success rate of root coverage, many clinicians have attempted to combine different procedures (Fig. 1, Fig. 2, Fig. 3, Fig. 4, Fig. 5). Nelson ${ }^{38}$ used connective tissue grafting with a double pedicle graft. A free connective tissue graft first was placed over the denuded root surface, followed by a double pedicle graft to partially cover the connective tissue graft. Twenty-nine defects were treated with that technique and monitored for 4 years. The mean root coverage was $88 \%$ (7-10 $\mathrm{mm}$ of recession), $92 \%$ (4-6 mm of recession), and $100 \%$ ( $\leq 3 \mathrm{~mm}$ of recession). Harris ${ }^{14}$ modified Nelson's technique with a split-thickness pedicle graft to cover the connective tissue graft. Thirty Miller class I and II defects were selected and the mean root coverage was $97 \%$.

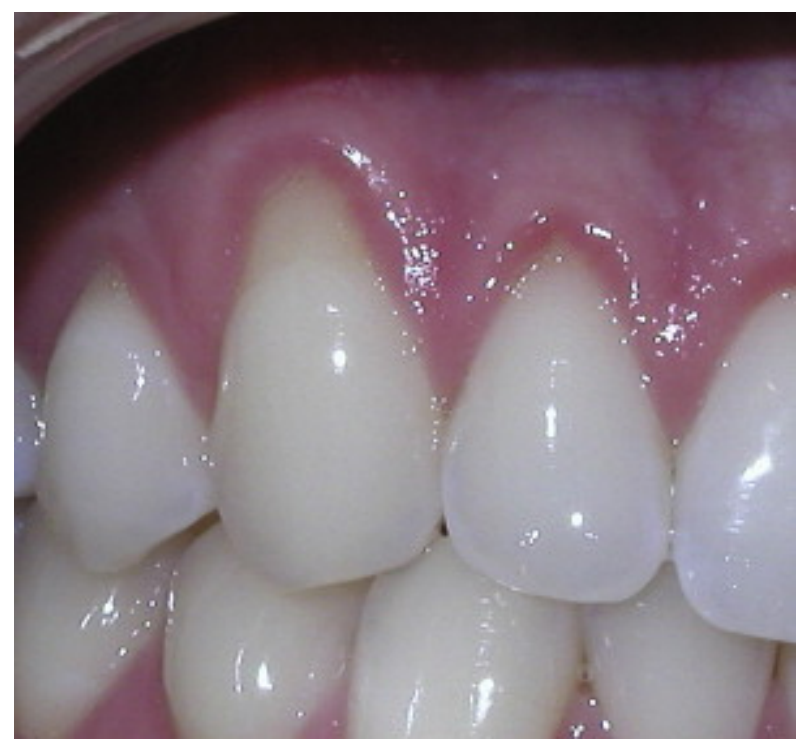

Fig. 1. Preoperative gingival recession on tooth \#6.

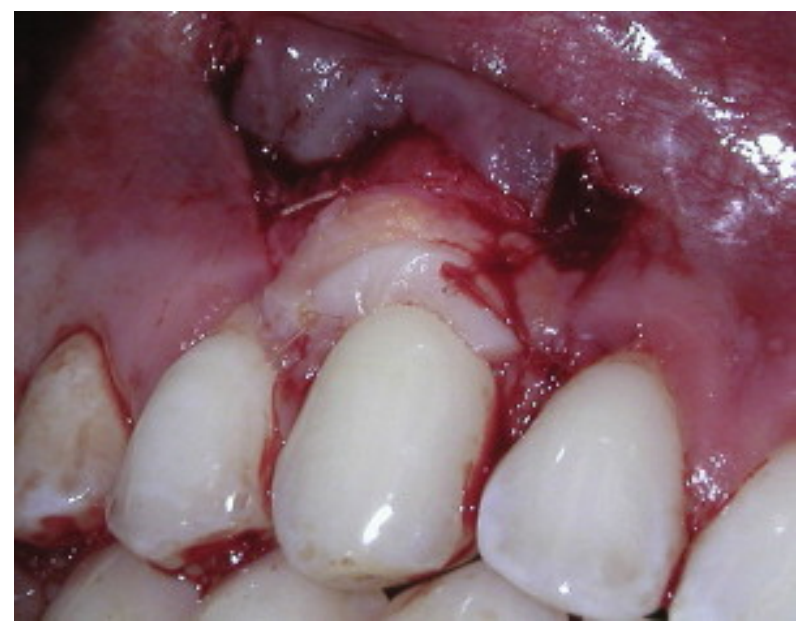


Fig. 2. Connective tissue graft sutured in place around tooth \#6.

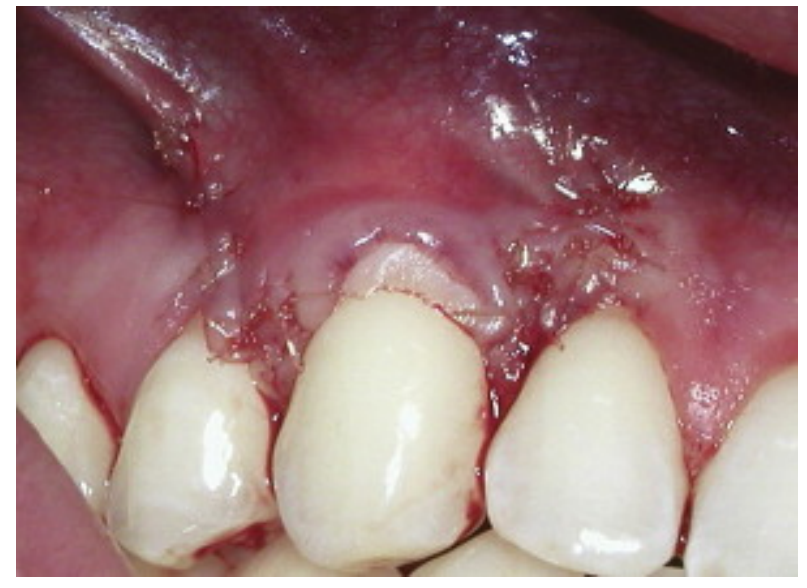

Fig. 3. Combination of connective tissue graft and coronally positioned flap with sutures at tooth \#6.

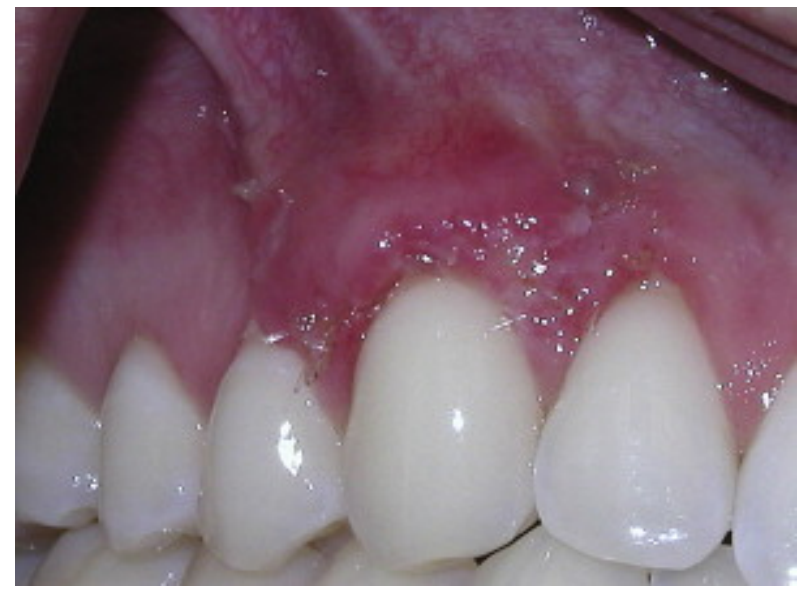

Fig. 4. Tooth \#6 after 2 weeks of postoperative healing.

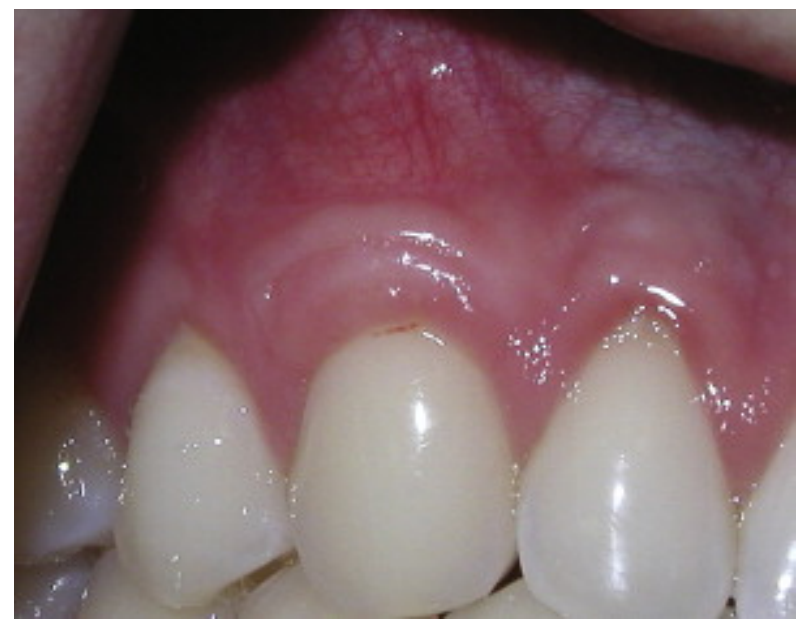


Fig. 5. Tooth \#6 after 6 months of postoperative healing.

Wennström and Zucchelli ${ }^{5}$ compared a coronally positioned flap to a combination of a coronally positioned and connective tissue graft procedure. The treatment of 103 (Miller class I and II) defects was performed. The success rate for the combination group was $98.9 \%$, while $97 \%$ was accomplished for the control group after a 2-year postoperative evaluation. The investigators concluded that the previous combination of coronally positioned flap and connective tissue graft was the treatment of choice to achieve root coverage.

Recent studies report that the addition of platelet-rich plasma to the combination of connective tissue grafting and coronally positioned grafts revealed no additional clinical benefits. $\underline{39}, \underline{40}$ Allografts have also been tested to treat gingival recession and to eliminate the donor site. Results appear to be contradictory, possibly because the procedure is technique sensitive, especially when aimed at root coverage. $\stackrel{41}{,} \underline{42}$

Various tissue engineering techniques, including those involving the use of enamel matrix derivative, have been used to enhance root coverage. However, minimal clinical significance has been reported in terms of root coverage. $\stackrel{43}{,}, \underline{44}, \underline{45}$

\section{Guided tissue regeneration (GTR) to treat gingival recession}

Regeneration is defined as "a reproduction or reconstitution of a lost or injured part. It is, therefore, the biologic process by which the architecture and function of lost tissues are completely restored.” $\underline{15}$ This implies regeneration of the tooth's supporting tissues, including alveolar bone, periodontal ligament, and cementum. Many studies have attempted to achieve regeneration, but success rates have varied from minimal or partial regeneration to almost complete regeneration.

The use of GTR has been suggested for treatment of recession. Tinti and Vincenzi ${ }^{46}$ first reported a case where GTR using an expanded polytetrafluoroethylene (ePTFE) membrane was used to treat recession defects. Cortellini, Clauser, and Pini Prato ${ }^{47}$ also demonstrated, histologically, that the root coverage obtained with an ePTFE membrane included new connective tissue attachment as well as new bone formation.

Different space-making solutions also have been used in combination with nonresorbable membranes (eg, titanium-reinforced, gold bar-reinforced, and gold frame-reinforced membranes) to increase the percentage of root coverage with GTR. In a human histologic study using titanium-reinforced membranes, there was evidence of new connective tissue attachment and new bone growth after 9 months. $\underline{48}$ The different membrane designs have resulted in $77 \%$ root coverage. $\underline{49}$

Roccuzzo and colleagues ${ }^{50}$ used ePTFE membranes in combination with miniscrews for space-making and stabilization, reporting a mean root coverage of $84 \%$ in 12 cases. Jepsen and colleagues $\underline{51}$ compared titanium-reinforced membranes and connective tissue grafts using the envelope technique. There was no statistically significant difference in the two treatment modalities (the mean root coverage was $87 \%$ for the GTR group and $86 \%$ for the connective tissue graft group). Wang and colleagues $\underline{52}$ also compared GTR to subepithelial connective tissue grafting. Using 16 patients with bilateral Miller class I and II recession, they concluded that both treatments presented with statistically significant improvement from 
preoperative to postoperative measurements. The mean root coverage for the GTR group was $73 \%$, and $84 \%$ for the subepithelial connective tissue graft.

To eliminate the need for a second surgical procedure to remove a nonresorbable membrane, the use of various bioabsorbable materials has been proposed. In one study, root coverage was obtained using a bioabsorbable polylactic acid membrane softened with citric acid ester (PLACA membrane). $\underline{53}$ In another study, the PLACA membrane resulted in a mean root coverage of $64 \% . \underline{54}$ In comparing the use of a PLACA membrane to a nonresorbable ePTFE membrane, investigators found no statistically significant differences in the mean root coverage obtained by either technique (PLACA 82\%; ePTFE 83\%). $\underline{50}$ Similarly, Zucchelli and colleagues $\underline{55}$ showed similar results when they compared bioabsorbable to nonabsorbable membranes.

The choice of GTR or gingival grafting to obtain root coverage has been a controversial subject. For example, Pini Prato and colleagues $\underline{\underline{56}}$ compared the results obtained with ePTFE membrane and a twostep mucogingival surgical procedure (involving a free gingival graft and coronally positioned flap). They reported mean root coverage for the GTR procedure of $72 \%$ versus mean root coverage for the two-step procedure of $70 \%$ (the differences were not statistically significant). Harris $\frac{57}{}$ also compared GTR with a bioabsorbable membrane versus connective tissue with double pedicle graft, and the difference was not statistically significant.

The combination of coronally positioned flap procedures and GTR was assessed in a clinical investigation. $\frac{58}{7}$ The investigators found in their 6-month split-mouth randomized design that there was no statistically significant difference between GTR/coronally positioned flaps versus coronally positioned flaps alone. The mean root coverage was 56\% and 69\%, respectively. Another study reported similar results, with no statistically significant differences observed between the two treatment groups. $\underline{59}$ However, the later study reported a slight increase in the width of keratinized gingiva in the connective tissue group. Ricci and colleagues ${ }^{60}$ also showed similar results after a 1-year postoperative evaluation, with no statistically significant differences between treatments (77\% mean root coverage for the GTR group and $80 \%$ for the connective tissue group). Harris $\frac{61}{}$ combined a connective tissue graft with a coronally positioned graft and compared it to GTR with a bioabsorbable membrane. No differences were observed between groups (92\% for the GTR group and 95\% for the connective tissue with coronally positioned graft). He also noticed a greater increase in the amount of keratinized gingival tissue for the connective tissue graft group. Trombelli and colleagues $\underline{62}$ showed a significant difference in mean root coverage when comparing the GTR with a bioabsorbable membrane to a connective tissue graft procedure (48\% root coverage for the GTR group and 81\% root coverage for the connective tissue graft), and reported a significant increase in the amount of keratinized gingival tissue for the connective tissue graft when compared with the GTR group. However, in a more recent study, $\underline{63}$ when GTR was compared with connective tissue grafting with coronally positioned flaps, the investigators concluded that, in shallow recessions (1.5 to $3.5 \mathrm{~mm}$ ), GTR techniques only provided 50\% root coverage obtained 12 months postoperatively, while the connective tissue grafting techniques yielded $82 \%$ root coverage. Harris $\frac{64}{}$ supported the previous conclusion by reporting that $92 \%$ mean root coverage obtained 6 months postoperatively had been reduced to a 58\% after a mean of 25 months' postoperative evaluation. 


\section{Summary}

The treatment of gingival recession can be accomplished with a variety of procedures. However, the combination of connective tissue grafting with a coronally positioned flap has been shown to demonstrate the highest success rate. Allograft materials and GTR techniques also can be used to treat recessions, particularly when patients are reluctant to consent to providing gingiva donor sites.

\section{References}

1 R.G. Smith Gingival recession. Reappraisal of an enigmatic condition and a new index for monitoring, J Clin Periodontol, 24 (1997), pp. 201-205

2 J.M. Albandar, A. Kingman Gingival recession, gingival bleeding, and dental calculus in adults $\mathbf{3 0}$ years of age and older in the United States, 1988-1944, J Periodontol, 70 (1999), pp. 30-43

3 W.J. Gorman The prevalence and etiology of gingival recession, J Periodontol, 38 (1967), pp. 316-322

$4 \mathrm{~J} . J$. Murray Gingival recession in tooth types in high fluoride and low fluoride areas, J Periodont Res, 8 (1973), pp. 243-253

5 J.L. Wennström, J. Zucchelli Increased gingival dimensions. A significant factor for successful outcome of root coverage procedures. A 2 year prospective clinical study, J Clin Periodontol, 23 (1996), pp. 770-777

$6 \mathrm{~J}$. Pfeifer, R. HellerHistologic evaluation of full and partial thickness lateral repositioned flaps: a pilot study, J Periodontol, 42 (1971), pp. 331-333

7 E.F. Sugarman A clinical and histologic study of the attachment of grafted tissue to bone and teeth, J Periodontol, 40 (1969), pp. 381-387

8 D.L. Wood, F.M. Hoag, O.W. Donnenfeld, et al. Alveolar crest reduction following full and partial thickness flaps, J Periodontol, 43 (1972), pp. 141-144

9 H.E. Grupe, R.F. Warren Repair of gingival defects by a sliding flap operation, J Periodontol, 27 (1956), pp. 290-295

10 P.D. Miller, E.P. Allen The development of periodontal plastic surgery, Periodontol 2000, 11 (1996), pp. 7-17

$11 \mathrm{H}$. Corn Edentulous area pedicle grafts in mucogingival surgery, J Periodontol, 2 (1964), pp. 229-242

12 A.B. Hattler Mucogingival surgery utilization of interdental gingival as attached gingiva by surgical displacement, J Periodontol, 5 (1967), pp. 126-131

13 D.W. Cohen, S.E. Ross The double papillae repositioned flap in periodontics, J Periodontol, 39 (1968), pp. 6570

14 R.J. Harris The connective tissue and partial thickness double pedicle graft: a predictable method of obtaining root coverage, J Periodontol, 63 (1992), pp. 477-486

15 The American Academy of Periodontology Annals of periodontology world workshop in periodontics. vol. 1. num. 1, The American Academy of Periodontology, Journal of Periodontology, Chicago (IL) (1996),p. 621

16 J.P. Bernimoulin, B. Luscher, H. Muhlemann Coronally repositioned periodontal flap, J Clin Periodontol, 2 (1975), pp. 1-13

17 J.G. Maynard Coronal positioning of a previously placed autogenous gingival graft, J Periodontol, 48 (1977), pp. 151-155

18 E.A. Guinard, R.G. Caffesse Treatment of local recession. Part III. Comparison of results obtained with lateral sliding and coronally repositioned graft, J Periodontol, 49 (1978), pp. 457-461

19 R.G. Caffesse, E.A. Guinard Treatment of localized recessions. Part IV. Results after three years, J

Periodontol, 51 (1980), pp. 167-170 
20 E.P. Allen, P.D. Miller Coronal positioning of existing gingiva: short-term results in the treatment of shallow marginal tissue recession, J Periodontol, 60 (1989), pp. 316-319

21 R.J. Harris The connective tissue with partial thickness double pedicle graft. The result of $\mathbf{1 0 0}$ consecutively treated defects, J Periodontol, 65 (1994), pp. 448-461

22 D.P. Tarnow Semilunar coronally repositioned flap, J Clin Periodontol, 13 (1986), pp. 182-185

23 H.C. Sullivan, J.H. Atkins Free autogenous gingival grafts. III. Utilization of grafts in the treatment of gingival recession, J Periodontol, 6 (1968), pp. 152-159

24 U. Egli, W. Vollmer, K.H. Rateikschaick Followup studies of free gingival grafts, J Clin Periodontol, 2 (1975), pp. 98-104

25 S.E. Soehren, A.L. Alien, D.E. Cutright, et al. Clinical and histologic studies of donor tissue utilized for free grafts of masticatory mucosa, J Periodontol, 44 (1973), pp. 727-741

26 H.S. Dorfman, J.E. Kennedy, W.C. Bird Longitudinal evaluation of free gingival autografts, J Clin Periodontol, 7 (1980), pp. 316-324

27 H.S. Dorfman, J.E. Kennedy, W.C. Bird Longitudinal study of free autogenous gingival grafts. A 4-year report, J Periodontol, 53 (1982), pp. 349-352

$28 \mathrm{~T}$. Holbrook, C. Ochsenbein Complete coverage of the denuded root surface with a one stage gingival graft, Int J Periodontics Restorative Dent, 3 (3) (1983), pp. 9-27

29 P.D. Miller Root coverage using the free soft tissue autograft following citric acid application. III. A successful and predictable procedure in areas of deep wide recession, Int J Periodontics Restorative Dent, 5 (2) (1985), pp. 15-37

30 B. Langer, L. Langer Subepithelial connective tissue graft technique for root coverage, J Periodontol, 56 (1985), pp. 715-720

31 P. Raetzke Covering localized areas of root exposure employing the "envelope" technique, J Periodontol, 56 (1985), pp. 397-402

32 A.L. Allen Use of the supraperiosteal envelop in the soft tissue grafting for root coverage. II. Clinical results, Int J Periodontics Restorative Dent, 14 (1994), pp. 303-315

33 P.V. Jahnke, J.P. Sandifer, M.E. Gher, et al. Thick free gingival graft and connective tissue autografts for root coverage, J Periodontol, 64 (1993), pp. 315-322

$34 \mathrm{~A}$. Borghetti, F. Louis Controlled clinical evaluation of the subpedicle connective tissue graft for the coverage of gingival recession, J Periodontol, 65 (1994), pp. 1107-1112

35 P. Bouchard, D. Etienne, J. Ouhayoun, et al. Subepithelial connective tissue grafts in the treatment of gingival recession. A comparative study of 2 procedures, J Periodontol, 65 (1994), pp. 929-936

36 M. Paolantonio, C. Muro, A. Cattabriga, et al. Subpedicle connective tissue graft versus free gingival graft in the coverage of exposed root surfaces. A 5 year clinical study, J Clin Periodontol, 24 (1997), pp. 51-56

37 R.J. Harris A comparison of two techniques for obtaining a connective tissue graft from the palate, Int J Periodontics Restorative Dent, 17 (1997), pp. 261-271

$38 \mathrm{~S}$. Nelson The subpedicle connective tissue graft. A bilaminar reconstructive procedure for the coverage of denuded root surfaces, J Periodontol, 95 (1986), p. 102

39 P.S. Petrungaro Using platelet-rich plasma to accelerate soft tissue maturation in esthetic periodontal surgery, Compend Contin Educ Dent, 22 (2001), pp. 729-732

40 L.H. Huang, R.E. Neiva, S.E. Soehren, et al. The effect of platelet-rich plasma on the coronally advanced flap root coverage procedure: a pilot human trial, J Periodontol, 76 (2005), pp. 1768-1777 
41 R.J. Harris A comparative study of root coverage obtained with an acellular dermal matrix versus a connective tissue graft: results of $\mathbf{1 0 7}$ recession defects in $\mathbf{5 0}$ consecutively treated patients, Int J Periodontics Restorative Dent, 20 (2000), pp. 51-59

42 G. Papageorgakopoulos, H. Greenwell, M. Hill, et al. Root coverage using acellular dermal matrix and comparing a coronally positioned tunnel to a coronally positioned flap approach, $J$ Periodontol, 79 (6) (2008), pp. 1022-1030

43 M.K. McGuire, M. Nunn Evaluation of human recession defects treated with coronally advanced flaps and either enamel matrix derivative or connective tissue. Part 1: comparison of clinical parameters, $J$ Periodontol, 74 (2003), pp. 1110-1125

44 M.K. McGuire, M.E. Nunn Evaluation of the safety and efficacy of periodontal applications of a living tissueengineered human fibroblast-derived dermal substitute. I. Comparison to the gingival autograft: a randomized controlled pilot study, J Periodontol, 76 (2005), pp. 867-880

45 M.K. McGuire, E.T. Scheyer, M.E. Nunn, et al. A pilot study to evaluate a tissue-engineered bilayered cell therapy as an alternative to tissue from the palate, J Periodontol, 3 (2008), pp. 1847-1856

$46 \mathrm{C}$. Tinti, G. Vincenzi The treatment of gingival recession with guided tissue regeneration procedure by means of Gore-Tex membranes, Quintessence Int, 6 (1990), pp. 465-468

47 P. Cortellini, C. Clauser, G. Pini Prato Histological assessment of new attachment following the treatment of a human buccal recession by means of a guided tissue regeneration procedure, $J$ Periodontol, 64 (1993), pp. 387-391

48 S. Parma-Benfenati, C. Tinti Histologic evaluation of new attachment utilizing a titanium-reinforced barrier membrane in a mucogingival recession defect. A case report, J Periodontol, 69 (1998), pp. 834-839

49 C. Tinti, G. Vincenzi, R. Cocchetto Guided tissue regeneration in mucogingival surgery, J Periodontol, 64 (1993), pp. 1184-1191

50 M. Roccuzzo, M. Lungo, G. Corrente, et al. Comparative study of a bioresorbable and a non-resorbable membrane in the treatment of human recessions, J Periodontol, 67 (1996), pp. 7-14

$51 \mathrm{~K}$. Jepsen, B. Heimz, H. Halben, et al. Treatment of gingival recession with titanium reinforced barrier membranes versus connective tissue grafts, J Periodontol, 69 (1998), pp. 383-391

52 H.L. Wang, P. Bunyaratavej, M. Labadie, et al. Comparison of 2 clinical techniques for treatment of gingival recession, J Periodontol, 72 (10) (2001), pp. 1301-1311

53 P. Genon, C. Genon-Romagna, J. Gottlow Treatment of gingival recessions with guided tissue regeneration: a bioresorbable barrier, J Periodontol Implantol Orale, 13 (1994), pp. 289-296

54 G. Pini Prato, C. Clauser, C. Magnani, et al. Resorbable membranes in the treatment of human buccal recession: a nine-case report, Int J Periodontics Restorative Dent, 15 (1995), pp. 258-267

55 G. Zucchelli, C. Clauser, M. De Sanctis, et al .Mucogingival versus guided tissue regeneration procedures in the treatment of deep recession type defects, J Periodontol, 69 (1998), pp. 138-145

56 G. Pini Prato, C. Tinti, G. Vincenzi, et al. Guided tissue regeneration versus mucogingival surgery in the treatment of human buccal recession, J Periodontol, 63 (1992), pp. 919-928

57 R.J. Harris A comparative study of root coverage obtained with guided tissue regeneration utilizing a bioabsorbable membrane versus the connective tissue with partial-thickness double pedicle graft, $J$ Periodontol, 68 (1997), pp. 779-790

58 E.S. Amarante, K.N. Leknes, J. Skavland, et al. Coronally positioned flap procedure with or without a bioabsorbable membrane in the treatment of human gingival recession, J Periodontol, 71 (2000), pp. 989-998 
59 A. Borghetti, J. Glise, V. Monnet-Corti, et al .Comparative clinical study of a bioabsorbable membrane and subepithelial connective tissue graft in the treatment of human gingival recession, $\mathrm{J}$ Periodontol, 70 (1999), pp. 123-130

60 G. Ricci, M. Silvestri, C. Tinti, et al. A clinical/statistical comparison between the subpedicle connective tissue graft method and the guided tissue regeneration technique in root coverage, Int J Periodontics Restorative Dent, 16 (1996), pp. 538-545

61 R.J. Harris A comparison of 2 root coverage techniques: guided tissue regeneration with a bioabsorbable matrix style membrane versus a connective tissue graft combined with a coronally positioned pedicle graft without vertical incisions. Results of series of consecutive cases, J Periodontol, 69 (1998), pp. 1426-1434

62 L. Trombelli, A. Scabbia, D.N. Tatakis, et al. Subpedicle connective tissue graft versus guided tissue regeneration with bioabsorbable membrane in the treatment of human gingival recession defects, $J$ Periodontol, 69 (1998), pp. 1271-1277

63 H.P. Muller, M. Stahl, T. Eger Failure of root coverage of shallow gingival recessions employing GTR and bioresorbable membrane, Int J Periodontics Restorative Dent, 21 (2001), pp. 171-181

64 R.J. Harris GTR for root coverage: a long-term follow-up, Int J Periodontics Restorative Dent, 22 (2002), pp. $55-61$ 